\title{
PRODUCTION ON AN OLD IRRIGATED PASTURE
}

Winchmore Irrigation Research Station, Ashburton

\begin{abstract}
Lamb meat production from an irrigated old ryegrass pasture farmlet is reported for the following conditions in successive years:-

Year 1 and 2: Stocked at 18 ewes plus 5 ewe replacements/ha $\boldsymbol{z}$ dry summers

Year 3: Same stocking rate as year 1 - moist summer

Year 4: Stocking rate reduced to 15 ewes plus 4 replacements/ha - dry summer

Year 5: Same stocking rate as year 4 - wet summer

Mean carcass weight for all iambs in years 1.5 was respectively 12.0, 12.4, 13.4, 12.0 and 14.2

$\mathrm{kg}$; lamb meat production was respectively 241, 257, 252, 214 and $262 \mathrm{~kg} / \mathrm{ha}$

At high stocking rates, in the years with dry summers, early drafting of light weight lambs was necessary so that other lambs could achieve a target carcase weight of $13-16 \mathrm{~kg}$. However ewe lambs did not reach that target. For two years with reduced stocking rate, dry summer weather in one of these years still precluded ewe lambs from reaching the target. In the other year with wet summer weather, production per lamb and per hectare was satisfactory.

Further management means of increasing production of heavy weight lamb are discussed.
\end{abstract}

Keywords: Pasture yields, lamb production, carcase weight, wool production

\section{INTRODUCTION}

In 1949 at the outset of irrigation research on the Winchmore Station of the Ministry of Agriculture and Fisheries, an 11 ha demonstration farmlet was set up to show the level of lamb and wool production that could be achieved. Since then there has been no renewal of the original ryegrass white clover pasture.

Romney ewes were run on the farmlet during the first 23 years and replacement ewes were purchased. From 1952 to 1981 stocking rate increased from 16.3 to 22.2 ewes/ha. From 1975 ewe replacements were changed from Romney to Coopworth and from 1981 these were bred rather than purchased. Stocking rate was then 18.3 ewes plus 5 replacements per ha. From 1981182 the objective of this demonstration has been to obtain a target of $13-16 \mathrm{~kg}$ carcase weight for lambs. This paper reviews the results from this five year period. Production in previous years has been reported by Moss (1985)

\section{METHODS}

The farmlet is on a Lismore stony silt loam, a free draining soil typical of much of the Canterbury Plains. The irrigation schedule of a minimum return period of 21 days between irrigations is similar to that available to farmers. On average there were six applications of water per year. All hay and silage was made on the farmlet. No pasture was renewed. There have been no pasture pest problems despite no insecticides since 1965. Annual applications of superphosphate averaged $238 \mathrm{~kg} / \mathrm{ha}$ until 1962, then changed to $375 \mathrm{~kg} / \mathrm{ha}$ until 1979 . It has since averaged $220 \mathrm{~kg} / \mathrm{ha} /$ year In $19852.5 \mathrm{t} / \mathrm{ha}$ of lime was applied, the previous application being in 1964 .

Stocking rate was 18.3 ewes and 5 hoggets in 1981182, 1982183 and 1983184 seasons, then decreasing to 15.3 ewes and 4 hoggets in 1984185 and 1985186. Grazing management in spring was generally rotational, around six paddocks $/ \mathrm{mob}$, with a rotation length of about 20 days. In 1985186 ewes were set-stocked following lambing. Pasture growth from early November until late December that was surplus to feed requirements was made into hay and silage. The silage was fed to ewes over a 3-4 week period in late summer. The grazing rotation for lambs, post-weaning, was 
initially 25 days but as lambs were removed for slaughter, the rotation was progressively increased to average 45 days by early March. Ewes followed the grazing lambs. The removal of lambs for slaughter commenced during early January and was usually completed by late April. During flushing, ewe liveweight was increased by 3-4 $\mathrm{kg}$ over the 4 week period prior to mating in mid-April to average 59 $\mathrm{kg}$. From mid-May, ewes were strip-grazed for 100 days, shifting to a fresh strip of pasture every 2 days. They were fed hay as necessary, averaging 0.5 bales/ewe/yr. From 3 weeks prior to lambing ewes were shifted daily.

Ewe lamb replacements were selected in late summer. They were separately grazed from the ewes until they joined them in the following March, then weighing 56 $\mathrm{kg}$ liveweight.

\section{RESULTS AND DISCUSSION}

Table 1 shows that with an irrigation schedule of 21 days, annual and seasonal herbage production varied considerably, notably during summer.

Table 1: Pasture Derformance

\begin{tabular}{lccccc}
\hline & Winter & Spring & \multicolumn{3}{c}{ Drymatter production: t/ha } \\
& Summer & Autum n & Total \\
\hline 1961182 & not available .. & & & & \\
1982183 & 1.4 & 5.0 & 3.8 & 2.0 & 12.2 \\
1983164 & 0.8 & 4.6 & 5.1 & 2.7 & 13.2 \\
1984185 & 1.4 & 5.3 & 3.9 & 2.3 & 12.9 \\
$1985 / 86$ & 1.2 & 5.2 & 5.6 & 3.1 & 15.3 \\
\hline
\end{tabular}

Table 2 shows low summer rainfall in three of the five years and in this circumstance, pastures suffered moisture stress prior to irrigation and hence yield was reduced. Consequently, the ability to finish all lambs to heavy weights was restricted.

Table 2: December-March rainfall $(\mathrm{mm})$ at Winchmore

\begin{tabular}{lrcrcc}
\hline & Dec & Jan & Feb & Mar & Dec-Mar \\
\hline 1981182 & 50 & 33 & 23 & 52 & 156 \\
1982183 & 80 & 39 & 15 & 43 & 177 \\
1963184 & 104 & 95 & 78 & 139 & 416 \\
1984185 & 54 & 11 & 74 & 37 & 176 \\
1985166 & 97 & 44 & 115 & 144 & 400 \\
\hline Long term mean & 70 & 65 & 56 & 70 & 261 \\
\hline
\end{tabular}

At the high stocking rate in the years 1981.83 lamb meat production/ha (Table 3) was similar despite differences in summer herbage production. For the years with low summer rainfall, 1981182 and 1982183, drafts of light lambs were taken in mid-late January so that the remainder could be retained to heavier weights. The lambs drafted early were those with a lower carcase weight potential. In $1981182,17 \%$ of ram lambs and $41 \%$ of ewe lambs were drafted early in the $8-12.5 \mathrm{~kg}$ range. The remaining ram lambs subsequently attained $13.5-14.9 \mathrm{~kg}$ carcase weights and. ewe lambs $11.6 \mathrm{~kg} \mathrm{(46 \% )}$ and $14.2 \mathrm{~kg}(13 \%)$. Even with the assistance of early drafting, the majority of remaining ewe lambs did not reach the target weight. In 1982183 Only ewe lambs (50\%) were drafted early, at light carcase weights of $9.8 \mathrm{~kg}$. Most of the ram lambs subsequently drafted at $12.9-14.1 \mathrm{~kg}$. The remainder of the ewe lambs drafted to $12.1 \mathrm{~kg}$ and so again did not reach the target weights.

In 1983184 when the summer was more favourable for pasture growth, early drafting of lambs was not necessary. Ram lambs drafted at 13.6-14.3 kg. Ewe lambs did not draft until late March and overall $48 \%$ did not reach the target weight. The unsatisfactory performance of the ewe lambs reflects the retention of the better 


\begin{tabular}{|c|c|c|c|c|c|c|}
\hline & \multirow[b]{2}{*}{$\begin{array}{c}\text { Lambing } \\
\% \\
\text { LT/EJ }\end{array}$} & \multicolumn{3}{|c|}{ Meat Sales } & \multirow[b]{2}{*}{$\begin{array}{l}\text { - Total wool } \\
\mathrm{t} \mathrm{t}_{\mathrm{kg} / \mathrm{ha}}^{\mathrm{o}} \mathrm{n}\end{array}$} & \multirow{2}{*}{$\begin{array}{c}\text { Mean draft } \\
\text { Date }\end{array}$} \\
\hline & & $\begin{array}{l}\text { Lamb } \\
\text { kg/lamb }\end{array}$ & $\begin{array}{l}\text { Lamb } \\
\mathrm{kg} / \mathrm{ha}\end{array}$ & $\begin{array}{c}M \quad \text { u } \\
\mathrm{kg} / \mathrm{ha}\end{array}$ & & \\
\hline 1981182 & 137 & 12.0 & 241 & 83 & 131 & $19 \mathrm{Feb}$ \\
\hline 1982183 & 145 & 12.4 & 257 & 70 & 137 & $21 \mathrm{Feb}$ \\
\hline 1983184 & 134 & 13.4 & 252 & 86 & 130 & 13 March \\
\hline 1984185 & 147 & 12.0 & 214 & 49 & 122 & 17 March \\
\hline 1985186 & 153 & 14.2 & 262 & 60 & 120 & 24 April \\
\hline
\end{tabular}

lambs, (about $38 \%$ of available ewe lambs) as replacements. A further contributing factor would have been the lower feed quality of the herbage as shown in the high content of dead material and lower content of white clover than in the two previous years.

In these three years production of heavy weight carcases, particularly of ewe lambs, was not satisfactory as shown in the overall mean weight per lamb (Table 3). Thus the decision was made to reduce stocking rate for the subsequent years so that ewe lambs in particular could be retained longer to achieve heavier carcase weights.

Lamb production per hectare was considerably lower during 1984185 than in the previous three years and, despite reduced stocking rate, mean carcase weight was not improved (Table 3). Summer of 1984185 was particularly dry and with reduced pasture production, $50 \%$ of ram lambs were drafted prior to mid-February at 11.2-I 1.4 $\mathrm{kg}$ carcase weight. Even after this was done and ewes fed silage during February, liveweight gain of remaining lambs was poor, averaging $45 \mathrm{~g} /$ day from mid January until mid March. Drafts of the remainder of the ram lambs were at $12.5-12.8 \mathrm{~kg}$ carcase weight. Ewe lambs did not draft until late March and overall $80 \%$ did not reach target weight.

Having failed to achieve the desired carcase weights with rotational grazing of ewes and lambs during spring and summer, change was made in 1985/86 to setstocking in spring attempting to improve pasture quality for increased lamb growth. This practice has been shown by Hay (1985) to improve clover growth in summer. This year was considerably wetter than the previous. Lamb meat production per hectare was higher than the previous year as was mean carcase weight (Table 3). Because of more adequate summer feeding, liveweight gain of ewe lambs was $160 \mathrm{~g} /$ day post. weaning, but they were assessed by the drafter to be overfat. They were therefore shorn and restricted in feeding over 3-4 weeks to reach grading requirements. Ram lambs were thus able to be retained longer, so that their overall carcase weights averaged $15.2 \mathrm{~kg}$. In this year, advancing the lambing date by $\mathbf{1 0}$ days and with later drafting, performance of the system was the best of the five years. The change to set. stocking was not seen to be an improvement in that year. During lactation, lamb growth was apparently affected in the three week period whilst the grazing area was restricted to provide post-weaning feeding for lambs. There was also no apparent improvement in available clover content of the farmlet. During the wet summer, competition from grass growth would have been limiting clover growth.

As mutton sales generated only $4 \%$ of gross income during the five years, its production was accorded a low priority. Production ranged from $55 \mathrm{~kg} / \mathrm{ha}$ to $80 \mathrm{~kg} / \mathrm{ha}$ at the low and high stocking rates respectively (Table 3 ), reflecting changes in stocking rates and a culling rate which was similar for all years.

Total wool production ranged from 120 to $137 \mathrm{~kg} / \mathrm{ha}$ (Table 3). As management ensured uniform between year ewe liveweight changes, their wool production varied only slightly, averaging $4.1 \mathrm{~kg}$ annually. Reducing the stocking rate therefore reduced production of ewe wool from 74 to $63 \mathrm{~kg} / \mathrm{ha}$. Lambs produced $30 \%$ of the wool. Their production, averaging $1.6 \mathrm{~kg} / \mathrm{lamb}$ and $38 \mathrm{~kg} / \mathrm{ha}$, was uniform during 1981-84. 
Improved summer and autumn feeding during 1985186 increased lamb wool production to $2.1 \mathrm{~kg} / \mathrm{lamb}$ and $48 \mathrm{~kg} / \mathrm{ha}$.

The potential of old permanent pasture to meet the requirements for heavy weight lean lamb production may have been reached at about $260 \mathrm{~kg}$ meat/ha for the present stocking rate, with ewe replacements bred in the system. To increase beyond that will require either higher growth rate of lambs in summer or their retention for longer periods. Specialist legume stands may be necessary for the former purpose. Lucerne has not persisted under irrigation. The use of pure red clover has not been investigated. Current research by Grasslands Division, DSIR at Lincoln shows particular promise. White clover contribution to Roa tall fescue pasture has been considerably higher than for perennial ryegrass pasture of similar age (pers comm T.J. Fraser).

Earlier lambing would require an earlier supply of feed than is presently being achieved from old perennial ryegrass pasture. Delaying lamb finishing further into autumn would affect supply of feed for flushing ewes. Thus there is a need for a grass species with more growth in early spring and autumn than perennial ryegrass. Grasslands Matua prairie grass may fill that role.

The pastures on these light Canterbury soils have proved to be both permanent and highly productive, requiring only the application of a simple grazing management system, a moderate fertiliser input, minimal weed control measures and no insecticides. Therefore, there will be considerable resistance to altering this low cost system unless a marked sustainable change in production can be assured.

\section{Acknowledgements}

K.R. Bell for technical assistance

References

Moss R.A. 1985. Intensive sheep production under irrigation. Technical Report 19, Winchmore Irrigation Research Station.

Hay R.J.M. 1985. spring management of pasture to increase summer white clover growth. Proceedings Lincoln College Farmers Conference 7985. 